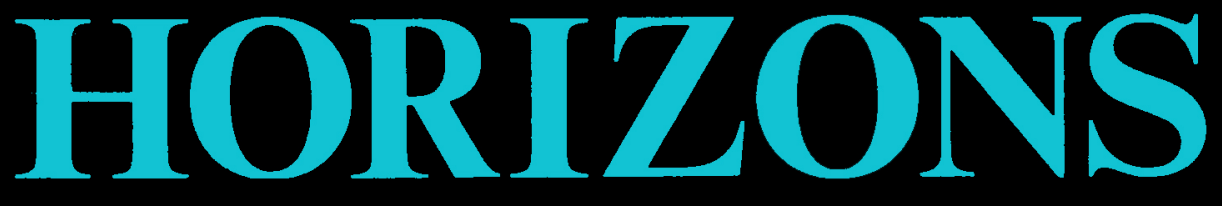

Volume 22

Spring, 1995

Number 1

\title{
ARTICLES
}

Joseph A. Bracken, S.J., Panentheism from a Trinitarian Perspective

Tiina Allik, Theory-Making, Transference, and Anthropology: On D. Z.

Phillips' Rejection of Nonfoundationalist Theorizing

Michael G. Lawler, Perichoresis: New Theological Wine in an

Old Theological Wineskin

James L. Fredericks, A Universal Religious Experience? Comparative Theology as an Alternative to a Theology of Religions

EDITORIAL ESSAY

William D. Lindsey, Telling It Slant: American Catholic Public Theology and Prophetic Discourse

\section{REVIEW SYMPOSIUM}

William L. Portier's Tradition and Incarnation: Foundations of Christion Theology

Five Perspectives: James J. Buckley; Marie Anne Mayeski; Bernard Cooke; Sandra Yocum Mize; Anthony J. Godzieba Author's Response: William L. Portier

\section{REVIEW ESSAY}

Rodger Van Allen, Law and Spirit in the Contemporary Catholic University

Plus Reviews of 29 Books 


\section{CROSSROAD THEOLOGY}

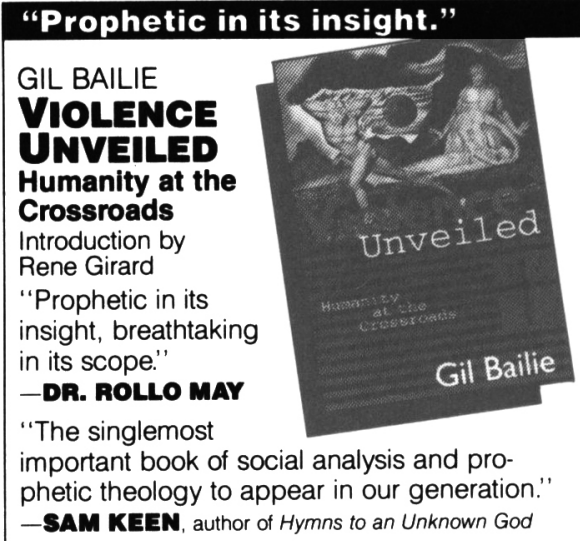

"A great book about Christianity and modern culture, a remarkable work of literary inter-

pretation."-RENE GIRARD.

author of Violence and the Sacred

"A book you will never forget . . . stunning filled with original insights and amazing perceptions." - ROBERT F. DRINAN, S.J. author of The Fractured Dream $\$ 24.95 \mathrm{hc}$

\section{A classic study.}

HELMER

RINGGREN

THE

FAITH

\section{OF}

\section{QUMRAN}

Theology of

the Dead

Sea Scrolls

A classic study of the

Dead Sea Scrolls

brought back to life

for a new and expanding readership.

Ringgren comprehensively treats the theological ideas in the Dead Sea Scrolls and focuses on the major themes of doctrine, organization and cult, and place within the history of religion. A new Introduction by James $\mathrm{H}$. Charlesworth portrays the importance of this book in light of recent controversy and research.

$\$ 17.95 \mathrm{pbk}$
"Best-theological book . . ."

AVERY

DULLES, S.J.

THE

Craft of THEOLOGY

From Symbol

to System

New expanded

paperback edition

of the "best

theological book of 1993."

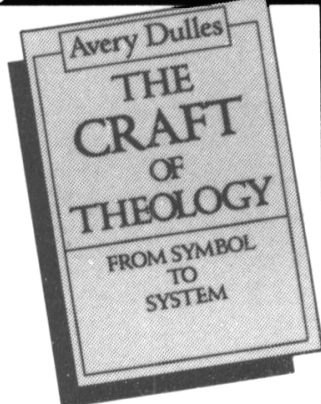

\section{-Catholic Press Association}

Exploring the possibilities for greater consensus, The Craft of Theology illustrates how a "post-critical" theology can draw on the riches of scripture and tradition as it reflects on the faith of the church in new contexts. Dulles discusses the freedom of theology within the university and sets forth principles for a fresh dialogue with philosophy, the sciences, and other Christian churches. $\$ 16.95$ pbk

\section{Flemish love mystic.}

PAUL

MOMMAERS

and JAN

VAN BRAGT

MYSTICISM BUDDHIST

AND

Christian

Encounters with Jan van Ruusbroec

An intriguing study of

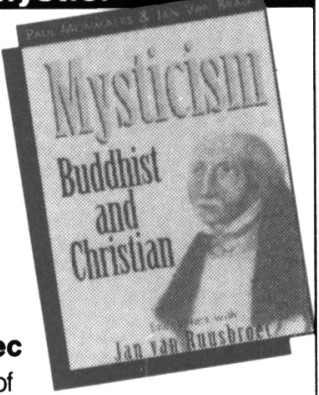

one of the greatest

mystical writers in Christian history. This comprehensive exploration of the works of Jan van Ruusbroec (1293-1381) is not only an original reading of the great Flemish love-mystic, but a groundbreaking attempt to view religious history through the dual lenses of one's own faith and that of the faith of others.

$\$ 29.95 \mathrm{hc}$ 


\title{
HORIZONS
}

\section{The Journal of the College Theology Society}

\author{
Published at Villanova University
}

Volume 22

Spring, 1995

Number 1

\section{ARTICLES}

Panentheism from a Trinitarian Perspective Joseph A. Bracken, S.J.

Theory-Making, Transference, and Anthropology:

On D. Z. Phillips' Rejection of

Nonfoundationalist Theorizing

Tiina Allik

Perichoresis: New Theological Wine in an Old Theological Wineskin

Michael G. Lawler

A Universal Religious Experience? Comparative

Theology as an Alternative to a

Theology of Religions

James L. Fredericks

\section{EDITORIAL ESSAY}

Telling It Slant: American Catholic Public

Theology and Prophetic Discourse

William D. Lindsey

\section{REVIEW SYMPOSIUM}

William L. Portier's Tradition and Incarnation: Foundations

of Christian Theology

Five Perspectives James J. Buckley 104 Marie Anne Mayeski 109 Bernard Cooke 111

Sandra Yocum Mize 113

Anthony J. Godzieba 116

Author's Response William L. Portier

REVIEW ESSAY

Law and Spirit in the Contemporary

Catholic University

Rodger Van Allen

\section{BOOK REVIEWS}

Christopher R. Seitz, Isaiah 1-39. Interpretation: A

Bible Commentary for Teaching and Preaching Alice L. Laffey 136

Ronald Quillo, Companions in Consciousness:

The Bible and the New Age Movement Joseph Martos 137

Gregory Boyd, Trinity and Process: A Critical

Evaluation and Reconstruction of Hartshorne's

Di-Polar Theism towards a

Trinitarian Metaphysics Joseph A. Bracken, S.J. 138 
Ted Peters, God as Trinity: Relationality and Temporality in Divine Life William P. Loewe 139

William V. Dych, S.J., Karl Rahner Mary E. Hines

Barbara Fiand, Embraced by Compassion: On Human Longing and Divine Response Janet K. Ruffing, R.S.M. 141

Frank T. Birtel, ed., Reasoned Faith: Essays on the Interplay of Faith and Reason Jeanne Evans 143

Linda Zagzebski, ed., Rational Faith: Catholic

Responses to Reformed Epistemology Terrence W. Tilley 144

Delores S. Williams, Sisters in the Wilderness:

The Challenge of Womanist God-Talk June O'Connor 145

Emilie M. Townes, ed., A Troubling in My Soul: Womanist Perspectives on Evil and Suffering Barbara Hilkert Andolsen 146

James B. Nelson and Sandra P. Longfellow, eds., Sexuality and the Sacred: Sources for Theological Reflection Elizabeth A. Dreyer 147

Paul Rorem, Pseudo-Dionysius: A Commentary on the Texts and an Introduction to Their Influence ..... John C. Cavadini 148 Anne Llewellyn Barstow, Witchcraze: A New

History of the European Witch Hunts Joan M. Nuth 149

Daniel A. Dombrowski, St. John of the Cross:

An Appreciation; Stephen Payne, O.C.D., ed., John of the Cross: Conferences and Essays by Members of the Institute of Carmelite Studies and Others Ernest E. Larkin, O.Carm. 150

Enrique Dussel, ed., The Church in Latin America, 1492-1992; Helen Rand Parish, ed., Bartolomé de las Casas: The Only Way; Luis N. Rivera, A Violent Evangelism: The Political and Religious Conquest of the Americas James B. Nickoloff 152

Robert L. Edwards, Of Singular Genius, of Singular Grace: A Biography of

Horace Bushnell Margaret M. McGuinness

Brigid O'Shea Merriman, O.S.F., Searching for

Christ: The Spirituality of Dorothy Day Mary Milligan, R.S.H.M. 156

William J. O'Brien, ed., Riding Time like a River:

The Catholic Moral Tradition since Vatican II Charles E. Curran 157 Philip S. Keane, S.S., Health Care

Reform: A Catholic View J. Milburn Thompson 158 John Courtney Murray, Religious Liberty:

Catholic Struggles with Pluralism William D. Lindsey 159

James F. Findlay, Jr., Church People in the Struggle:

The National Council of Churches and

the Freedom Movement, 1950-1970 Lawrence H. Mamiya 
Thomas Day, Where Have You Gone, Michelangelo?: The Loss of Soul in Catholic Culture Sandra Yocum Mize 162 Johannes Wilbert, Mystic Endowment: Religious Ethnography of the Warao Indians Carl F. Starkloff, S.J. 163 Groupe des Dombes, For the Conversion of the Churches Brother Jeffrey Gros, F.S.C. 164 Ruben L. F. Habito, Healing Breath: Zen

Spirituality for a Wounded Earth Christopher Key Chapple 165 John Kelsay, Islam and War: A Study in Comparative Ethics David B. Burrell, C.S.C. 166 BOOKS RECEIVED 168

Copyright $\odot 1995$ College Theology Society

Printed in the United States of America 


\section{HORIZONS}

\section{The Journal of the College Theology Society}

Horizons, The Journal of the College Theology Society is published biannually in Spring and Fall at Villanova University, Villanova, PA 19085.

Yearly subscription: individual $\$ 16.00$, institutional $\$ 34.00$. Send remittance, payable to Wilfrid Laurier University Press, to Wilfrid Laurier University Press, Wilfrid Laurier University, Waterloo, Ontario, Canada N2L 3C5. Changes of address should also be sent to this address. Horizons is automatically received through membership in the College Theology Society.

Manuscripts, editorial and business correspondence, book reviews, advertising copy, and orders for single issues (individual $\$ 8.00$, institutional $\$ 17.00$ ) should be addressed to The Editor, Horizons, Journal of the CTS, Villanova University, Villanova, PA 19085.

In submitting manuscripts, please send four clear copies. Author's name should appear only on an unpaginated cover sheet, with address and essay's title. No other identifying reference to author should appear on the manuscript. All references to author's work in text or notes should be in the third person. Essay's fitle should appear at top of first page of text. Notes should be placed on separate sheets at end. Full double spacing should be used throughout, including indented quotations and notes. Top, bottom, and right-hand margins should be at least one inch; left-hand margins at least one-and-a-half. Manuscripts should be accompanied by an abstract of one hundred fifty words or less and an author vita of one hundred words or less. Authors should state that the manuscript will not be submitted to another journal until Horizons' evaluation is completed. Manuscripts will be returned if postage is supplied.

Articles appearing in Horizons are abstracted and indexed in: The Catholic Periodical and Literature Index; Guide to Social Science and Religion in Periodical Literature; Index to Religious Periodical Literature; New Testament Abstracts; Religious and Theological Abstracts; and Social Science Citation Index. Articles are indexed in Religion Index One: Periodicals; book reviews indexed in Index to Book Reviews in Religion. Horizons is available in microform from University Microfilms International, 300 North Zeeb Road, Department P.R., Ann Arbor, MI 48106.

\section{(C) COLLEGE THEOLOGY SOCIETY}

The College Theology Society is a professional organization of college and university professors of religion in the United States and Canada.

The purpose of the College Theology Society is to improve the quality of the teaching of religion: by stimulating and sharing scholarly research; by developing programs of theology and religious studies which meet student needs and interests; and by exploring, evaluating, and encouraging effective ways of teaching which are interdisciplinary and ecumenical.

Annual membership dues in the Society are $\$ 40.00$ (Full Professional or Associate), $\$ 45.00$ (Joint Professional for husband and wife), and $\$ 20.00$ (Graduate Student). Membership in the Society includes a subscription to Horizons. Contact Gary Macy, Theological and Religious Studies Department, University of San Diego, Alcalá Park, San Diego, CA 92110. 


\section{EDITOR}

Walter E. Conn

Villanova University

\section{ASSOCIATE EDITORS}

Lisa Sowle Cahill

Boston College

Denise Lardner Carmody

University of Santa Clara

Anne Carr

The University of Chicago

Bernard Cooke

Incarnate Word College

Lawrence S. Cunningham

University of Notre Dame

Charles E. Curran

Southern Methodist University

Elisabeth Schüssler Fiorenza

Harvard Divinity School

Francis Schüssler Fiorenza

Harvard Divinity School
Paul F. Knitter

Xavier University

Elena Malits, C.S.C.

Saint Mary's College

Pheme Perkins

Boston College

Norbert J. Rigali, S.J. University of San Diego

Sandra M. Schneiders, I.H.M.

Jesuit School of Theology, Berkeley

William M. Shea

Saint Louis University

Gerard S. Sloyan

The Catholic University of America

William M. Thompson

Duquesne University

Mary Jo Weaver

Indiana University

BOOK REVIEW EDITOR

Joann Wolski Conn

Neumann College

BUSINESS EDITOR

Anne McGuire

Haverford College

EDITORIAL ASSISTANT

Irene C. Noble 


\section{HORIZONS}

\section{The Journal of the College Theology Society}

A journal exploring developments in Catholic theology, the total Christian tradition, human religious experience, and the concerns of creative teaching from the college and university environment.

The big news for us these days is a rare discovery - a typographical error! We have learned that on page 379 of the Fall 1994 issue the word "incorrigible" on line 11 should be "corrigible." We offer no excuse, but can suggest an explanation. It seems that the original "corrigible" in the typescript was changed to "incorrigible" during the production process - a change that was virtually invited, one might argue. Once it became "incorrigible," I suppose the change was irreversible and thus went undetected until it was too late. Apologies to the author.

The articles in this issue range from panentheism through transference and perichoresis to universal religious experience. There can be little corrigible here! Joseph Bracken considers "Panentheism from a Trinitarian Perspective." Not too many pages later Michael Lawler picks up with "Perichoresis: New Theological Wine in an Old Theological Wineskin." Tiina Allik reflects "On D. Z. Philips' Rejection of Non-foundationalist Theorizing" and James Fredericks on "A Universal Religious Experience."

In our Editorial Essay, William Lindsey relates Prophetic Discourse to American Catholic Public Theology. A Review Essay by Rodger Van allen examines two books on a topic important to many of us-American Catholic Higher Education. This issue's Review Symposium focuses on a book central to American Catholic Higher Education: William Portier's Tradition and Incarnation: Foundations of Christian Theology. Portier responds to reviews by James Buckley, Marie Anne Mayeski, Bernard Cooke, Sandra Yocum Mize, and Anthony Godzieba. There remain reviews of 29 books. 